\title{
Isolated Compounds from Turpinia formosana Nakai Induce Ossification
}

\author{
Zuha Imtiyaz ${ }^{1}$, Yi-Fang Wang ${ }^{2}$, Yi-Tzu Lin ${ }^{1}$, Hui-Kang Liu ${ }^{1,3}$ and Mei-Hsien Lee ${ }^{1,2,4, *(\mathbb{D})}$ \\ 1 Clinical Drug Development of Herbal Medicine, Graduate Institute of Pharmacognosy, Taipei Medical \\ University, Taipei 11031, Taiwan \\ 2 Graduate Institute of Pharmacognosy, College of Pharmacy, Taipei Medical University, Taipei 11031, Taiwan \\ 3 Division of Basic Chinese Medicine, National Research Institute of Chinese Medicine (NRICM), \\ Ministry of Health and Welfare, Taipei 112, Taiwan \\ 4 Center for Reproductive Medicine \& Sciences, Taipei Medical University Hospital, Taipei 11031, Taiwan \\ * Correspondence: $1 m h @ t m u . e d u . t w$
}

Received: 3 June 2019; Accepted: 24 June 2019; Published: 26 June 2019

\begin{abstract}
Bone metabolism is a homeostatic process, imbalance in which leads to the onset of diseases such as osteoporosis and osteopenia. Although several drugs are currently available to treat such conditions, they are associated with severe side effects and do not enhance bone formation. Thus, identifying alternative treatment strategies that focus on enhancing bone formation is essential. Herein, we explored the osteogenic potential of Turpinia formosana Nakai using human osteoblast $(\mathrm{HOb})$ cells. The plant extract was subjected to various chromatographic techniques to obtain six compounds, including one new compound: $3,3^{\prime}$-di-O-methylellagic acid-4-O- $\alpha-\mathrm{L}-$ arabinofuranoside (1). Compounds 3,3'-di-O-methylellagic acid-4-O- $\alpha$-L-arabinofuranoside (1), gentisic acid 5-O- $\beta$-D-(6'-O-galloyl) glucopyranoside (2), strictinin (3), and (-)-epicatechin-3-O- $\beta$-Dallopyranoside (6) displayed no significant cytotoxicity toward $\mathrm{HOb}$ cells, and thus their effects on various osteogenic markers were analyzed. Results showed that 1-3 and 6 significantly increased alkaline phosphatase (ALP) activity up to 120.0, 121.3, 116.4, and 125.1\%, respectively. Furthermore, 1,2 , and $\mathbf{6}$ also markedly enhanced the mineralization process with respective values of up to 136.4, 118.9 , and $134.6 \%$. In addition, the new compound, $\mathbf{1}$, significantly increased expression levels of estrogen receptor- $\alpha(133.4 \%)$ and osteogenesis-related genes of Runt-related transcription factor 2 (Runx2), osteopontin (OPN), bone morphogenetic protein (BMP)-2, bone sialoprotein (BSP), type I collagen (Col-1), and brain-derived neurotropic factor (BDNF) by at least 1.5-fold. Our results demonstrated that compounds isolated from $T$. formosana possess robust osteogenic potential, with the new compound, 1, also exhibiting the potential to enhance the bone formation process. We suggest that $T$. formosana and its isolated active compounds deserve further evaluation for development as anti-osteoporotic agents.
\end{abstract}

Keywords: bone formation; Turpinia formosana; 3,3'-di-O-methylellagic acid-4-O- $\alpha$-L-arabinofuranoside; mineralization; alkaline phosphatase; estrogen receptors; osteoporosis

\section{Introduction}

Osteoporosis is a common systemic disorder characterized by defects in the microarchitecture of bone tissue, increased fragility of bones, and reduced bone mass [1]. Bone, being a metabolically active tissue, undergoes continuous remodeling throughout life. Bone remodeling primarily comprises two processes, namely, ossification and bone resorption, which are respectively orchestrated by osteoblasts and osteoclasts derived from different progenitor pools and hence are controlled by distinct molecular mechanisms [2,3]. Bone remodeling is important for maintaining bone mass, 
repairing micro-damage, preventing the excessive accumulation of old bone, and maintaining mineral homeostasis [4]. An imbalance in this metabolism causes disorders such as osteoporosis.

Several classes of drugs are available to treat osteoporosis, the most common of which are the bisphosphonates, an antiresorptive class of drugs whose mode of action targets osteoclasts. Although these drugs were found to be effective at controlling osteoporosis, their long-term use is associated with adverse effects particularly in patients with lower risk of fractures $[5,6]$. Furthermore, they are highly associated with osteonecrosis of the jaw and atypical femur fractures [7]. In addition to bisphosphonates, estrogen replacement therapies and vitamin D and calcium supplements are also widely used to manage osteoporosis. While the former is associated with severe side effects, including venous thromboembolic disorders, breast cancer, endometrial cancer, and cortical porosity in cases of selective estrogen receptor (ER) modulators [8-10], the efficacy of the latter is uncertain. Thus, identifying alternative therapeutic strategies to improve existing options is paramount [11-13].

Transcription factors, proteins, and hormones play vital roles in bone metabolism. Alkaline phosphatase (ALP) is a key component of bone metabolism and is expressed early in the development of bone and calcification of cartilage tissues, as well as on the cell surface of osteoblasts and in matrix vesicles. However, in later stages of differentiation, while expressions of other genes (e.g., osteocalcin) is upregulated, ALP expression declines [14]. Runt-related transcription factor 2 (Runx2) is an upstream transcription factor essential for osteoblast differentiation. Runx2 is a well-characterized transcriptional regulator that is expressed by chondrocytes and osteoblasts [15], and it regulates the expression of the collagen alpha-1 X chain (Col10a1) [16]. Collagen interacts with several other factors responsible for bone strength, thus contributing to the mechanical properties of bone [17-19]. Osteopontin (OPN) is also a key factor that binds to various extracellular molecules, including osteocalcin (OCN), fibronectin, and type I collagen (Col-1), thereby adding physical strength to the extracellular matrix. OPN also promotes the attachment of bone cells to the bone matrix [20,21]. Estrogen is an essential hormone associated with bone formation as it is involved in the growth and maturation of bone as well as in the regulation of bone turnover in adults. In addition, estrogen is required for the closure of the epiphyseal plate during bone growth [22], and its deficiency causes an increase in the number of the osteoclasts, leading to enhanced bone resorption $[23,24]$.

Plant-derived compounds are an essential source of drug discovery and have been extensively explored against different disease conditions including osteoporosis. Members of the Staphyleaceae family of plants are rich in medicinal values $[25,26]$, particularly those belonging to the Turpinia genus. Turpinia ternate showed cytotoxicity against Artemia salina larvae [27]. T. pomifera was found to possess antimalarial activity against Plasmodium falciparum [25]. Roots of T. formosana are used in traditional Taiwanese medicine to reduce swelling and pain and unclog the blood circulation [28]. The plant has been documented to possess numerous medicinal activities including antiviral activity against influenza [29,30]. T. formosana is also used in traditional formula preparations for ankylosing spondylitis and cervical spondylosis [31]. Considering the numerous medicinal properties of the plant including its bone-related activities, we herein explored the osteogenic effect of $T$. formosana using human osteoblast $(\mathrm{HOb})$ cells.

\section{Results}

\subsection{Isolated Compounds from Turpinia formosana}

Column chromatography and semipreparative high-performance liquid chromatography (HPLC) were used for isolation and purification of compounds from the ethyl acetate (EtOAc) and $n$-butanol $(n-\mathrm{BuOH})$ layers, as depicted in Chart S1, Supplementary Materials. We identified six major compounds (see Scheme S1, Supplementary Materials). On the basis of physical and spectroscopic methods, we identified these compounds as 3,3'-di-O-methylellagic acid-4-O- $\alpha$-L-arabinofuranoside (1) (Figure S1A-E, supplementary material), gentisic acid 5-O- $\beta$-D-(6'-O-galloyl) glucopyranoside (2) (Figure S2A-E, supplementary material) [32], strictinin (3) (Figure S3A) [33], casuarinin (4) (Figure 
S4A-E) [33], casuariin (5) (Figure S5A-E) [33], and (-)-epicatechin-3-O- $\beta$-D-allopyranoside (6) (Figure S6A-E) [34] (see Figure 1). 3,3'-Di-O-methylellagic acid-4-O- $\alpha$-L-arabinofuranoside (1) is a new compound, being isolated and reported for the first time in our study.

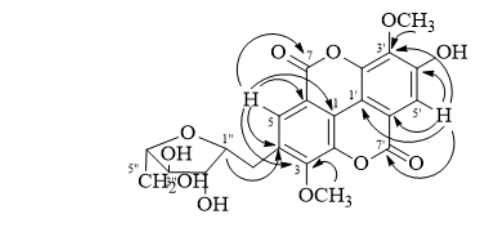

3,3'-di- $O$-methylellagic acid-4- $O$ - $\alpha$-L-arabinofuranoside (1)

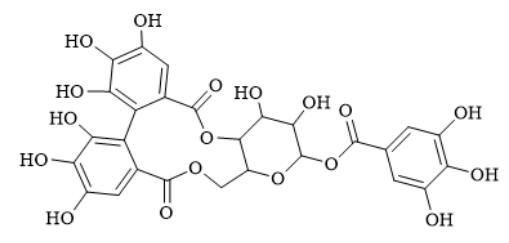

Strictinin (3)

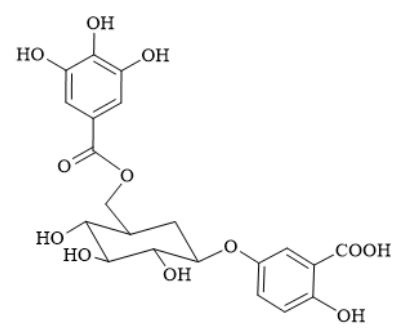

Gentisic acid 5-O- $\beta$-D-(6'-O-gallolyl) glucopyranoside (2)

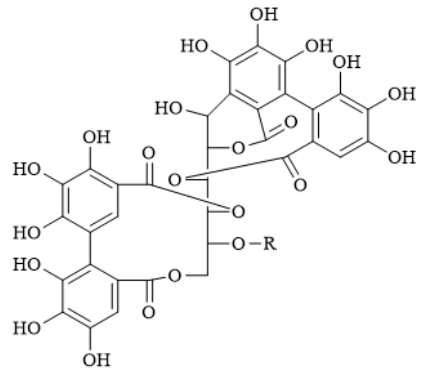

$\mathrm{OH}$

Casuarinin $(4) \mathrm{R}=$

Casuariin (5) $\mathrm{R}=\mathrm{H}$

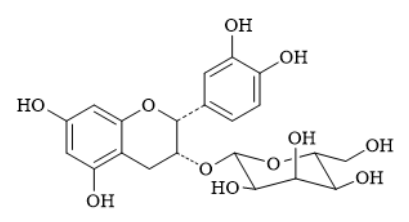

(-)-Epicatechin-3-O- $\beta$-D-allopyranoside (6)

Figure 1. Structure of compounds isolated from T. formosana.

\subsection{Structural Elucidation of New Compound 1 from T. formosana}

Compound 1 was obtained as a yellow amorphous powder and was isolated from the EtOAc layer of the T. formosana extract. Its molecular formula was established to be $\mathrm{C}_{21} \mathrm{H}_{18} \mathrm{O}_{12}$ based on the prominent pseudomolecular ion peaks at $m / z 461.1[\mathrm{M}-\mathrm{H}]^{-}$in electrospray ionization-mass spectroscopy (ESI-MS) and 461.0719 [M-H] $]^{-}$in high-resolution mass spectroscopy (HRMS). The UV spectrum of 1 exhibited absorption maxima in methanol $(\mathrm{MeOH})$ at 211, 246, and $367 \mathrm{~nm}$, which were possibly identified as carboxyl and phenyl groups, and benzene rings. The ${ }^{1} \mathrm{H}$ and ${ }^{13} \mathrm{C}$ nuclear magnetic resonance (NMR) spectra (DMSO- $d_{6}$ ) of $\mathbf{1}$ showed signals assignable to two non-equivalent methoxyl groups $\left[\delta_{\mathrm{H}} 4.03(3 \mathrm{H}, s) ; \delta_{\mathrm{C}} 61.4\left(3-\mathrm{OCH}_{3}\right)\right.$ and $\left.\delta_{\mathrm{H}} 4.07(3 \mathrm{H}, s) ; \delta_{\mathrm{C}} 61.0\left(3^{\prime}-\mathrm{OCH}_{3}\right)\right]$ and two aromatic protons $\left[\delta_{\mathrm{H}} 7.45\right.$ and $\delta_{\mathrm{H}} 7.70($ each $1 \mathrm{H}, s)$ ]. Compound 1 showed signals ascribable to a methylellagic acid moiety with seven pairs of quaternary carbons signals $\left[\delta_{\mathrm{C}} 113.8,110.8\left(\mathrm{C}-1,1^{\prime}\right) ; \delta_{\mathrm{C}} 141.4,140.8(\mathrm{C}-2\right.$, $\left.2^{\prime}\right) ; \delta_{C} 141.9,140.2\left(\mathrm{C}-3,3^{\prime}\right) ; \delta_{C} 150.7,152.9\left(\mathrm{C}-4,4^{\prime}\right) ; \delta_{C} 111.6,111.7\left(\mathrm{C}-5,5^{\prime}\right) ; \delta_{\mathrm{C}} 111.6,112.5\left(\mathrm{C}-6,6^{\prime}\right)$; $\left.\delta_{\mathrm{C}} 158.4,158.2\left(\mathrm{C}-7,7^{\prime}\right)\right][27,35]$. The moiety was also supported by the heteronuclear multiple-bond correlations (HMBCs) from $\mathrm{H}-5(\delta 7.70,1 \mathrm{H}, s)$ to $\mathrm{C}-1,-3,-4,-6$, and -7 as well as $\mathrm{H}-5^{\prime}(\delta 7.45,1 \mathrm{H}, s)$ to $\mathrm{C}-1^{\prime}$, $-3^{\prime},-4^{\prime},-6^{\prime}$, and $-7^{\prime}$. In addition, two-dimensional NMR spectroscopic data allowed the identification of sugar protons. Correlation spectroscopy (COSY) was used to determine the connectivity around the sugar from $\mathrm{H}-1^{\prime}$ to $\mathrm{H}-6^{\prime}\left[\delta_{\mathrm{H}} 5.63 / 4.23, \delta_{\mathrm{H}} 4.23 / 3.87, \delta_{\mathrm{H}} 3.87 / 3.97, \delta_{\mathrm{H}} 3.97 / 3.50, \delta_{\mathrm{H}} 3.97 / 3.62\right]$. Comparing with acid hydrolysis, the sugar was identified by HPLC analysis of $\mathbf{1}$ as $\alpha$-L-arabinose [36]. Long-range correlations seen in $\mathrm{HMBC}$ data were observed between $3-\mathrm{OCH}_{3}\left(\delta_{\mathrm{H}} 4.03,3 \mathrm{H}, \mathrm{s}\right)$ and $\mathrm{C}-3\left(\delta_{\mathrm{C}} 141.9\right)$; $3^{\prime}-\mathrm{OCH}_{3}\left(\delta_{\mathrm{H}} 4.07,3 \mathrm{H}, \mathrm{s}\right)$ and $\mathrm{C}-3^{\prime}\left(\delta_{\mathrm{C}} 140.2\right)$; and $\mathrm{H}-1^{\prime \prime}\left(\delta_{\mathrm{H}} 5.63\right)$ and $\mathrm{C}-4\left(\delta_{\mathrm{C}} 150.7\right)$. This showed the connectivity of the methoxy and arabinofuranosyl moieties in $\mathbf{1}$. Accordingly, $\mathbf{1}$ was characterized as the new ellagic acid derivative 3,3'-di-O-methylellagic acid-4-O- $\alpha$-L-arabinofuranoside (Table 1). 
Table 1. ${ }^{1} \mathrm{H}-\mathrm{NMR}$ and ${ }^{13} \mathrm{C}-\mathrm{NMR}$ spectral data of $\mathbf{1}$ ( $\delta$ values, in DMSO- $d_{6}, J$ in $\mathrm{Hz}$ ).

\begin{tabular}{|c|c|c|c|}
\hline Position & $\delta_{C}$ & $\delta_{H}($ multi, $J$ in $\mathrm{Hz})$ & HMBC $(\mathrm{H} \rightarrow \mathrm{C})$ \\
\hline \multicolumn{4}{|c|}{ methylellagic acid } \\
\hline 1 & 113.8 & & \\
\hline 2 & 141.4 & & \\
\hline 3 & 141.9 & & \\
\hline 4 & 150.7 & & \\
\hline 5 & 111.6 & $7.70(1 \mathrm{H}, s)$ & $C-1, C-3, C-4, C-6, C-7$ \\
\hline 6 & 111.6 & & \\
\hline 7 & 158.4 & & \\
\hline $1^{\prime}$ & 110.8 & & \\
\hline $2^{\prime}$ & 140.8 & & \\
\hline $3^{\prime}$ & 140.2 & & \\
\hline $4^{\prime}$ & 152.9 & & \\
\hline $5^{\prime}$ & 111.7 & $7.45(1 \mathrm{H}, s)$ & $\mathrm{C}-1^{\prime}, \mathrm{C}-3^{\prime}, \mathrm{C}-4^{\prime}, \mathrm{C}-6^{\prime}, \mathrm{C}-7^{\prime}$ \\
\hline $6^{\prime}$ & 112.5 & & \\
\hline $7^{\prime}$ & 158.2 & & \\
\hline $3-\mathrm{OCH}_{3}$ & 61.4 & $4.03(3 \mathrm{H}, \mathrm{s})$ & \\
\hline $3^{\prime}-\mathrm{OCH}_{3}$ & 61.0 & $4.07(3 \mathrm{H}, \mathrm{s})$ & \\
\hline \multicolumn{4}{|l|}{ arabinose } \\
\hline $1^{\prime \prime}$ & 107.5 & $5.63(1 \mathrm{H}, b r s)$ & $\mathrm{C}-4$ \\
\hline $2^{\prime \prime}$ & 82.1 & $4.23(1 \mathrm{H}, d, J=3.9 \mathrm{~Hz})$ & \\
\hline $3^{\prime \prime}$ & 76.6 & $3.87(1 \mathrm{H}, m)$ & \\
\hline $4^{\prime \prime}$ & 86.1 & $3.97(1 \mathrm{H}, m)$ & \\
\hline \multirow{2}{*}{$5^{\prime \prime}$} & 609 & $3.50(1 \mathrm{H}, m)$ & \\
\hline & 00.9 & $3.62(1 \mathrm{H}, m)$ & \\
\hline
\end{tabular}

J, coupling constant expressed in $\mathrm{Hz}$; s, singlet; brs, broad singlet; d, doublet; $\mathrm{m}$, multiplet; $\mathrm{H}$, proton; ' and ", depicts carbon position.

\subsection{Cytotoxicity of Compounds Isolated from T. formosana toward HOb Cells}

$\mathrm{HOb}$ cells were treated with the isolated compounds $(100 \mu \mathrm{M})$ for three days, before analyzing cell viability using 3-(4,5-dimethylthiazol-2-yl)-2,5-diphenyltetrazolium bromide MTT assay. Results showed that cell viability of groups treated with 1, 2, 3, and 6 were all above $80 \%$, and hence, we studied the osteogenic activities of those compounds (see Figure 2A).

\subsection{Effect of Isolated Compounds on ALP Activity in HOb Cells}

ALP is one of the early biomarkers of bone formation, and studies have shown that it plays a vital role in mineral deposition. Hence, we considered it a foundational biomarker like many other research groups. On treating $\mathrm{HOb}$ cells with $100 \mu \mathrm{M}$ of 1, 2, 3, and $\mathbf{6}$ for three days, an increase in the ALP activity was observed (data not shown). Following this observation, we next examined whether the compounds could increase ALP activity in a concentration-dependent manner. As depicted in Figure 2B, 1 and 2 exhibited a concentration-dependent increase in ALP activity with 60, 80, and $100 \mu \mathrm{M}$ increasing ALP activity up to 103.7, 108.8, and $120.0 \%$ for $\mathbf{1}$ and $108.9,117.0$, and $121.3 \%$ for $\mathbf{2}$, respectively. However, $\mathbf{3}$ and $\mathbf{6}$ only displayed a significant increase in ALP activity at concentrations of 80 and $100 \mu \mathrm{M}$. Specifically, 3 at 80 and $100 \mu \mathrm{M}$ increased ALP activity to 112.8 and $116.4 \%$, whereas the same concentrations for 6 increased ALP activity to 119.7 and $125.1 \%$, respectively $\left({ }^{*} p \leq 0.05\right.$, ** $p \leq 0.01$ compared to the control). 
A

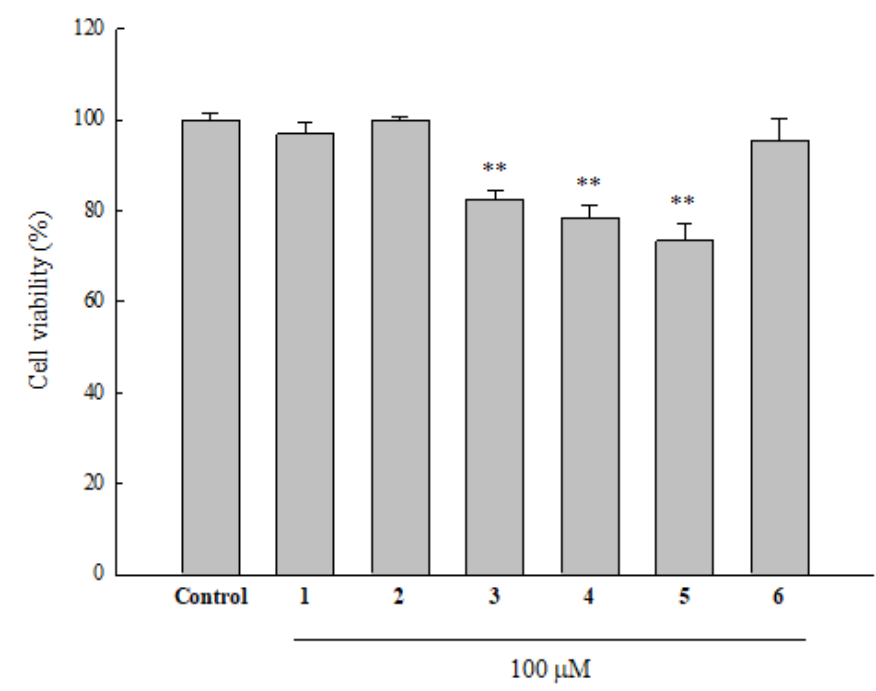

B

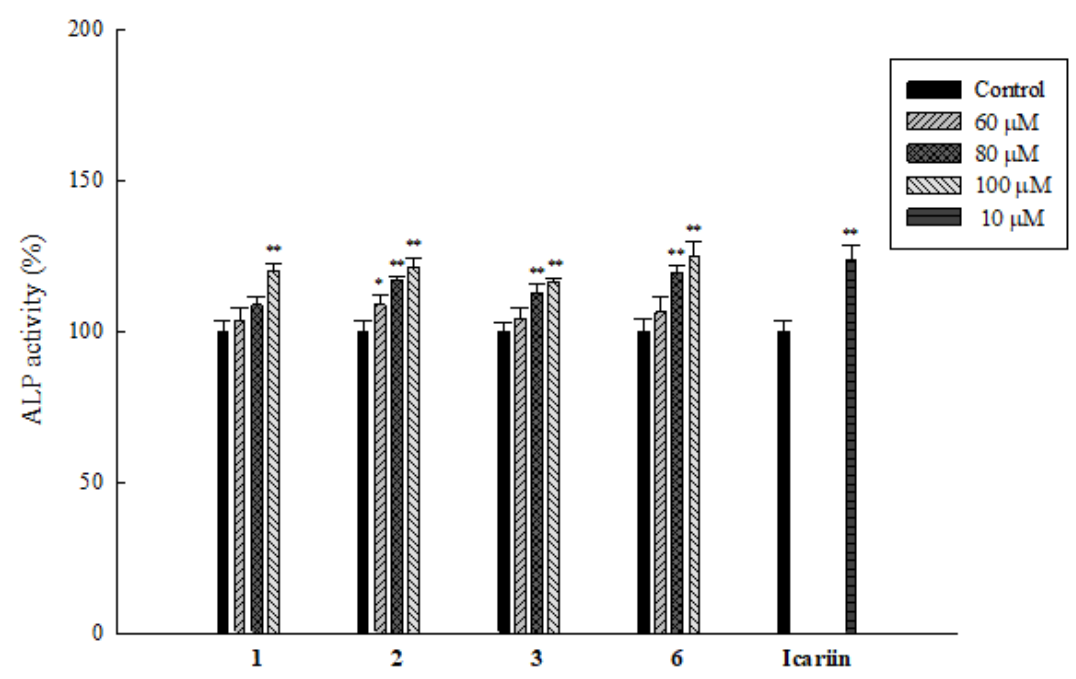

Figure 2. Cytotoxicity and induction ALP activity by isolated compounds in HOb cells. Cells were seeded in a 96-well plate, and after $24 \mathrm{~h}, 100 \mu \mathrm{M}$ samples were added. (A) After five days, an MTT assay was performed to analyze cell viability. (B) After three days, ALP activity was detected by performing an ALP assay using bicinchoninic acid (BCA) protein to normalize protein expression of cells. Data are expressed as the mean $\pm \mathrm{SD},{ }^{*} p \leq 0.05,{ }^{* *} p \leq 0.01$ compared to the control, and all experiments were performed in triplicate.

\subsection{Effect of Isolated Compounds on Mineralization in HOb Cells}

Extracellular matrix mineralization is an essential step in bone formation, which is controlled by several genetic pathways which regulate the homeostasis of minerals required for bone mineral formation [37]. On performing an alizarin red assay to determine mineralization by the active compounds at various concentrations, we found that while 1 and $\mathbf{6}$ at 80 and $100 \mu \mathrm{M}$ increased mineralization up to $110.8 \%, 136.4 \%$ for 1 and $120.8 \%$, and $134.6 \%$ for 6 , significant increase in mineralization was only observed at $100 \mu \mathrm{M}$ for 2 (118.9\%) and 3 (107.9\%) (Figure 3A,B). These results suggest that compared to $\mathbf{2}$ and $\mathbf{3}, \mathbf{1}$ and $\mathbf{6}$ are more effective at increasing mineral deposition in $\mathrm{HOb}$ cells. 
$\mathbf{A}$
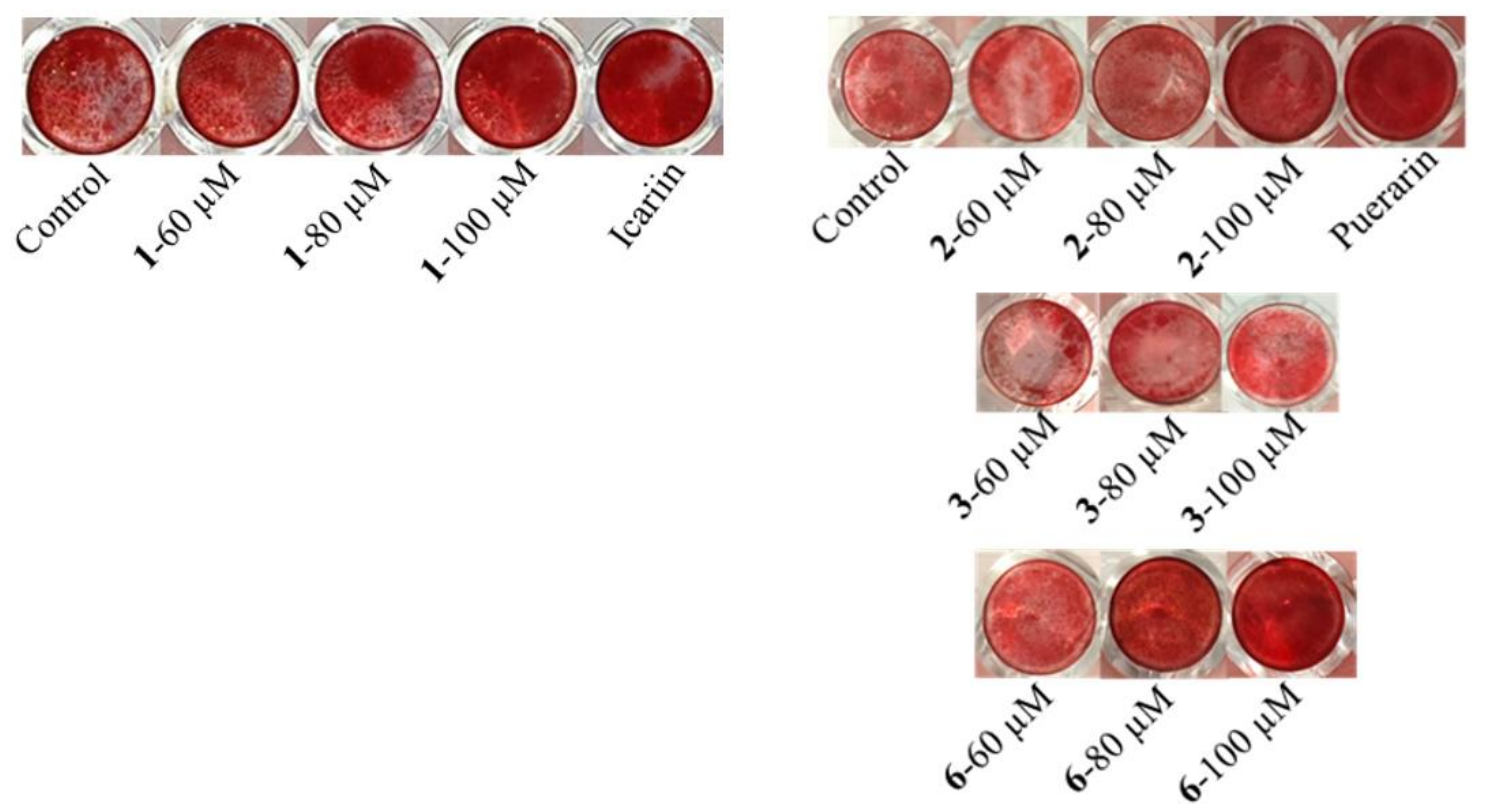

B

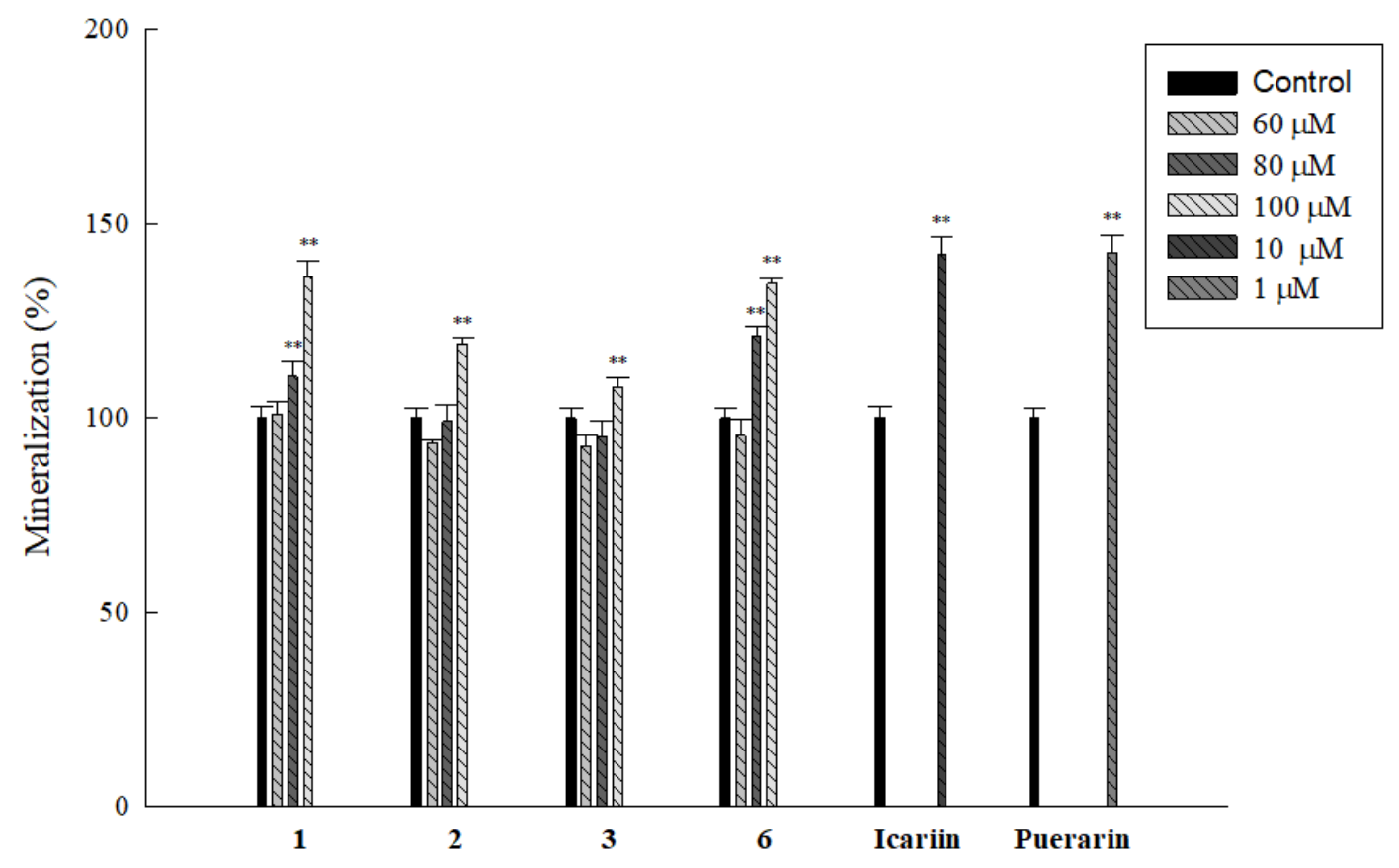

Figure 3. Isolated compounds increase mineralization in HOb cells. Cells were seeded in a 48-well plate for three days, after which fresh osteoblast differentiation media (ODM) miner containing inducers and samples were added. Subsequently, every two days, fresh ODM miner, inducers, and samples were added until the 11th day. Mineralization was then detected by performing an alizarin red assay. (A) Pictures show mineral deposition after addition of the alizarin red dye, and (B) the graph shows quantitative data obtained after adding 10\% cetylpyridinium chloride as a de-stain to dissolve the crystals. Data are expressed as the mean $\pm \mathrm{SD}\left({ }^{* *} p \leq 0.01\right.$ compared to the control), and all experiments were performed in triplicate. 


\subsection{Effect of Isolated Compounds on ER Expression in HOb Cells}

Studies showed the significance of ERs and their involvement in bone formation. In order to examine whether any of the active compounds modulate expression levels of ERs, we analyzed the effect of $\mathbf{1}, \mathbf{2}, \mathbf{3}$, and $\mathbf{6}$ on ER- $\alpha$ in HOb cells. Results showed that only $\mathbf{1}$ significantly increased protein expression of ER- $\alpha$ (see Figure 4A). Further analysis demonstrated that 1 increased ER- $\alpha$ expression in a concentration-dependent manner, with 60,80 , and $100 \mu \mathrm{M}$ of the compound increasing ER- $\alpha$ expression to $120.3,123.2$, and $133.4 \%$, respectively (see Figure $4 \mathrm{~B}$ ). This indicates that 1 modulates the expression of ER- $\alpha$, thus activating the related pathway. Furthermore, we also examined the effect of the compounds on ER- $\beta$ expression as it is believed to function as an antagonist to ER- $\alpha$. We found that whereas $\mathbf{3}$ and $\mathbf{6}$ had no significant effect on ER- $\beta, \mathbf{1}$ and $\mathbf{2}$ at $100 \mu \mathrm{M}$ significantly decreased the expression level of ER- $\beta$ up to 92.2 and $92.2 \%$, respectively (see Figure 4 A) ${ }^{* *} p \leq 0.01$ compared to the control).

$\mathbf{A}$

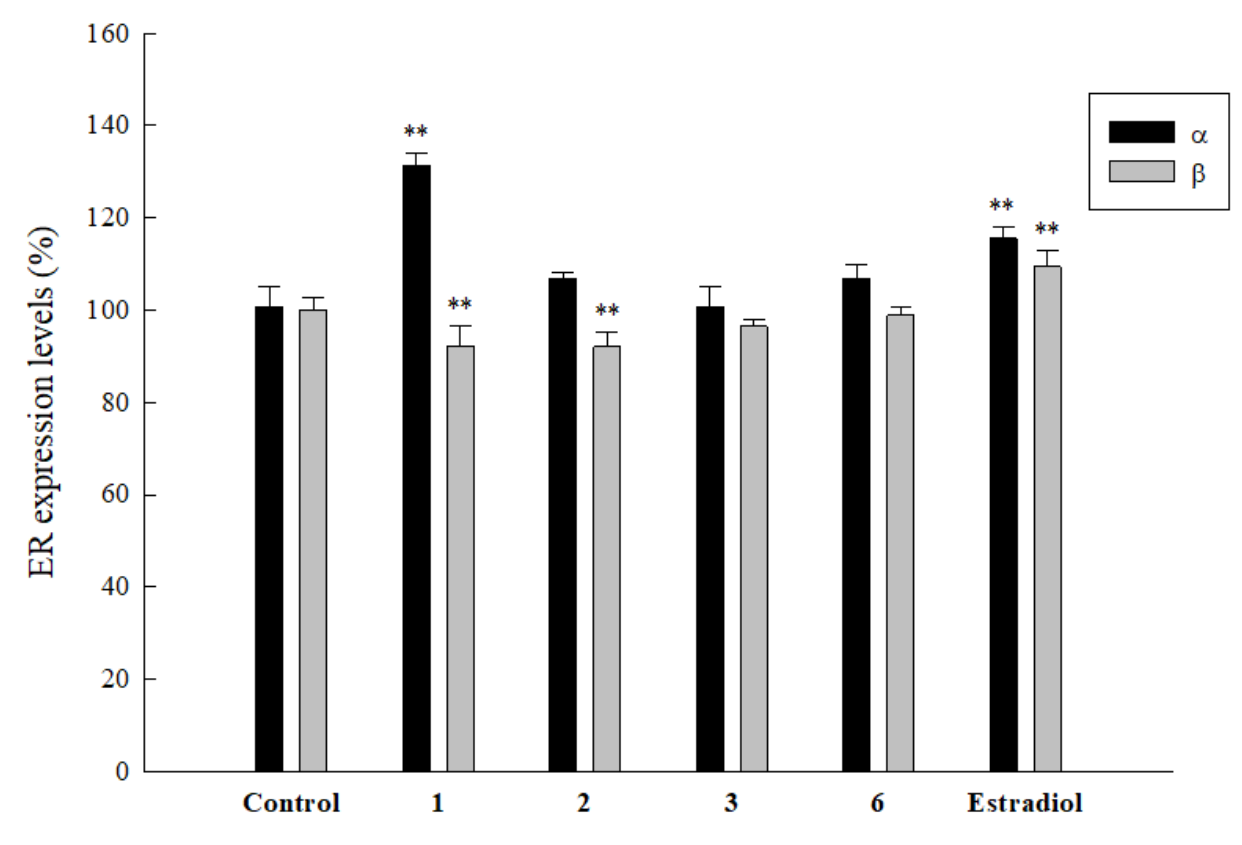

Figure 4. Cont. 


\section{B}

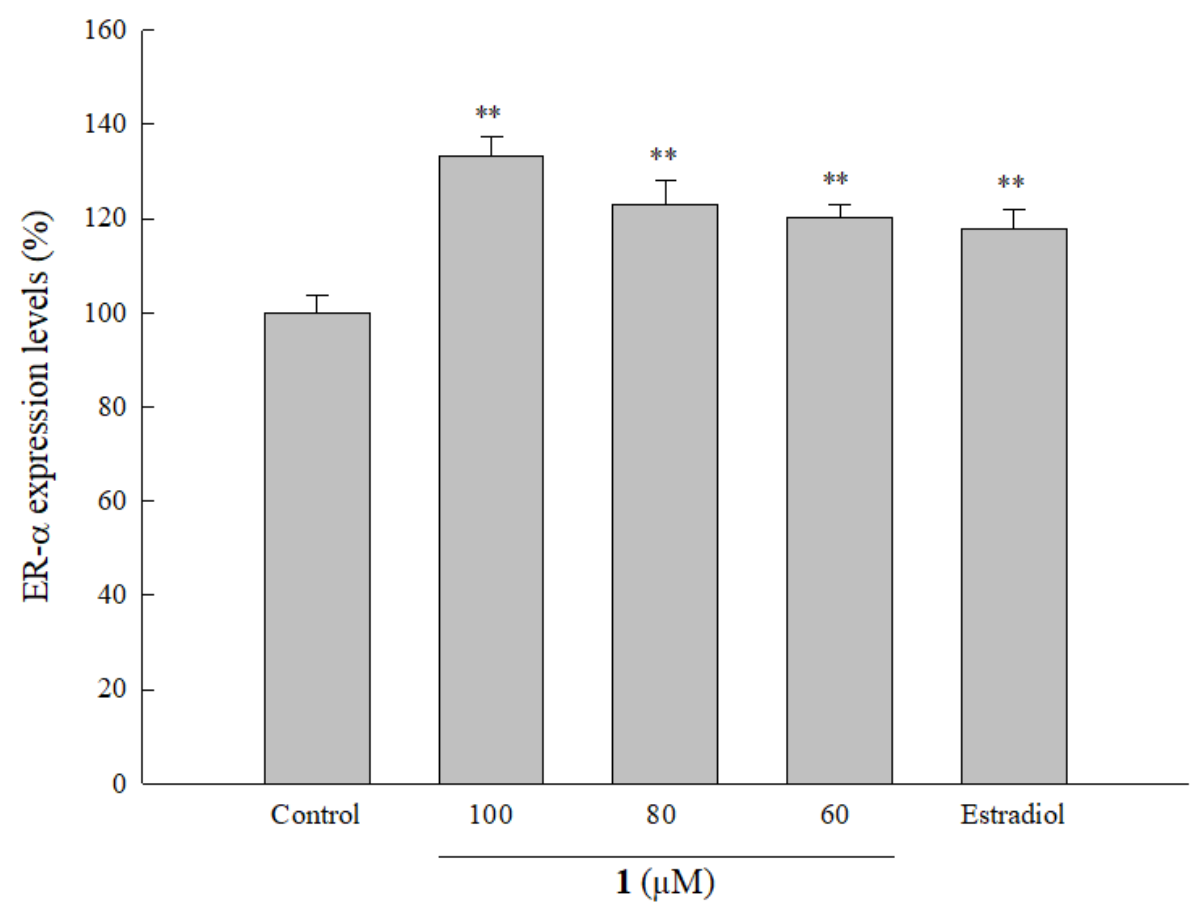

Figure 4. Effect of isolated compounds on ER expression in HOb cells. Cells were seeded in a 96-well plate and after $24 \mathrm{~h}, 100 \mu \mathrm{M}$ of samples and $1 \mu \mathrm{M}$ estradiol (positive control) were added. After five days, (A) ER- $\alpha / \beta$ expression levels were detected. (B) The dose-dependent effect of 1 on the expression of ER- $\alpha$ was analyzed. Data are expressed as the mean $\pm \mathrm{SD}$ (** $p \leq 0.01$ compared to the control), and all experiments were performed in triplicate.

\subsection{Effect of Isolated Compounds on Genetic Markers of Bone Formation in HOb Cells}

Bone metabolism is a complex process involving various pathways which interact to regulate bone formation. We tested the effect of all active compounds on the expression of certain key genes and transcription factors involved in osteoblastogenesis and osteoclast apoptosis in HOb cells. After treating cells with 1 for $24 \mathrm{~h}$, we observed a significant increase in the mRNA expression of all the tested genes, with the expression in OPN (2.9-fold) being the highest. Expression levels of bone morphogenetic protein (BMP)-2, brain-derived neurotropic factor (BDNF), Runx2, Col-1, and bone sialoprotein (BSP) were increased by 2.2-, 1.9-, 2.5-, 2.2-, and 2.3-fold respectively (see Figure 5A). Expression levels were higher compared to puerarin (the positive control) for all the markers except for BDNF and BSP. On analyzing the effect of 2, 3, and $\mathbf{6}$ on the same selected biomarkers, results showed that 3 increased the expression of Runx 2 by 1.8 -fold and 6 increased the expression of BMP-2 to 1.7 -fold, Figure $5 \mathrm{~B},{ }^{*} p \leq 0.05,{ }^{* *} p \leq 0.01$ compared to the control. These results demonstrated that in contrast to other active compounds, $\mathbf{1}$ had a significant effect on all of the selected biomarkers, thereby identifying it as a potent osteogenic inducer. 
A

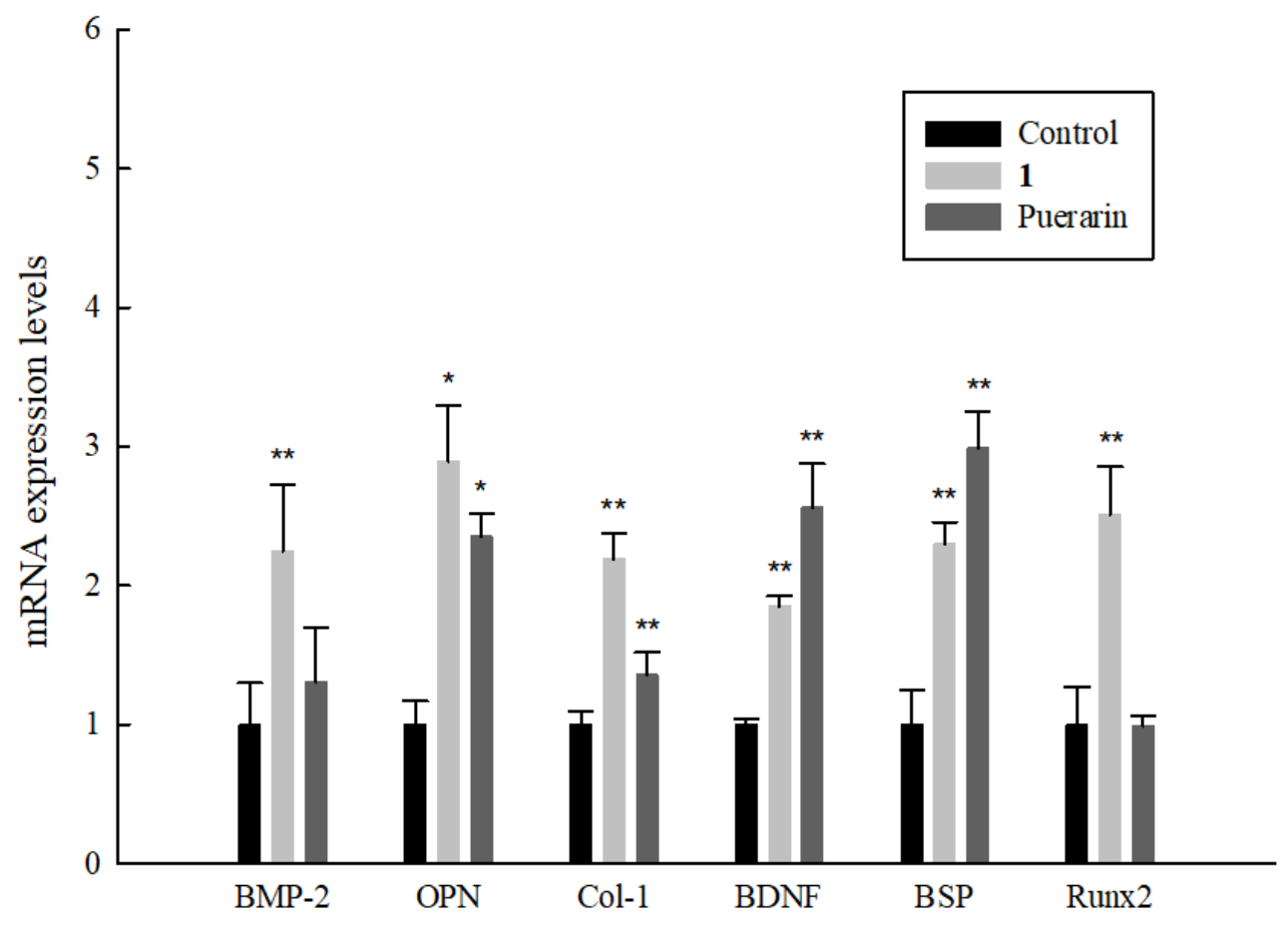

B

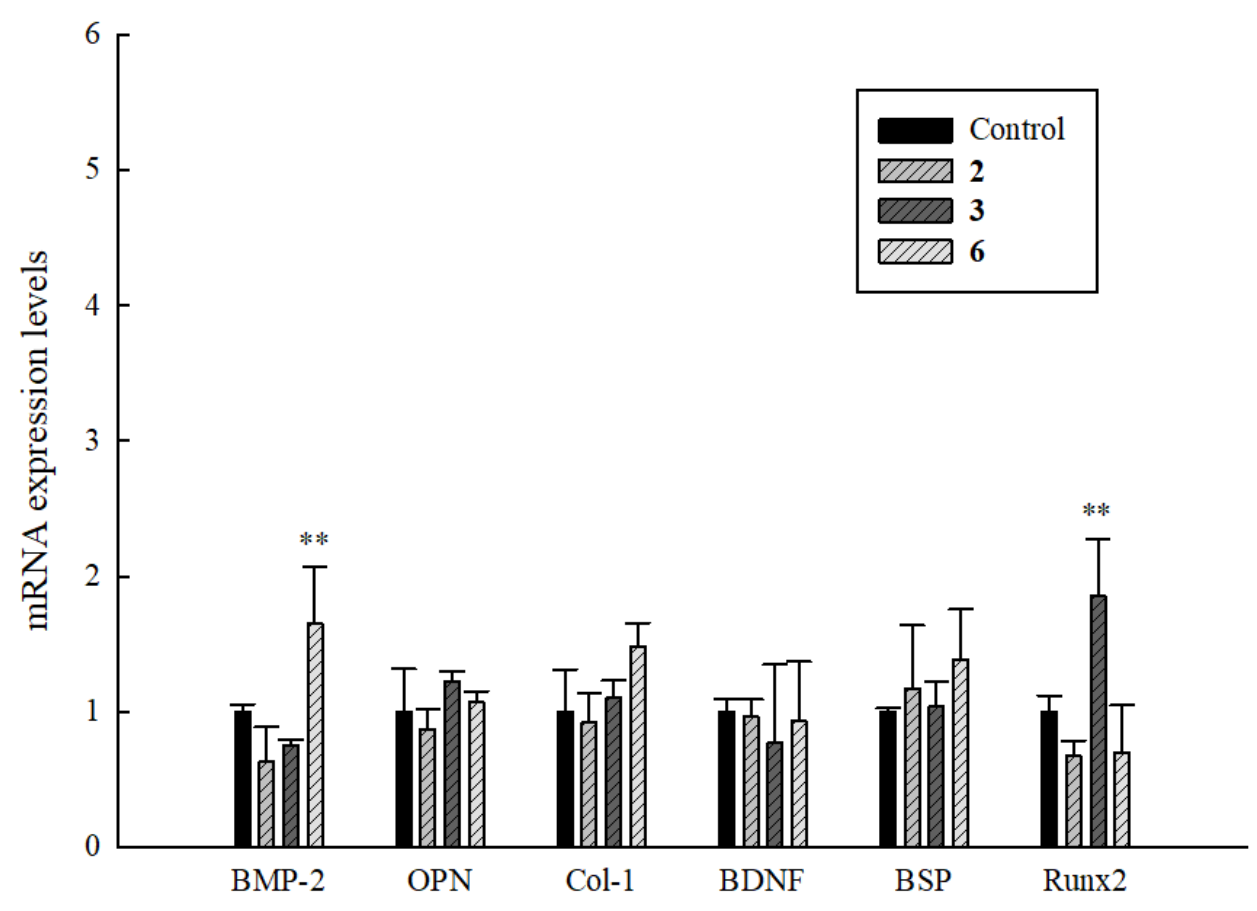

Figure 5. Effect of active compounds on bone formation-related genes in $\mathrm{HOb}$ cells. Cells were seeded in 6-cm dishes and after $24 \mathrm{~h}$, fresh ODM containing (A) $100 \mu \mathrm{M}$ of 1 and $1 \mu \mathrm{M}$ puerarin (the positive control), or (B) $100 \mu \mathrm{M}$ of 2, 3, and $\mathbf{6}$ was added to cells. This was followed by mRNA isolation and reverse transcription. Expression levels were detected by performing a real-time PCR. Data are expressed as the mean $\pm \mathrm{SD}\left({ }^{*} p \leq 0.05,{ }^{* *} p \leq 0.01\right.$ compared to the control), and all experiments were performed in triplicate. 


\section{Discussion}

Nature-derived compounds serve as an essential source of drug discovery. An increasing body of evidence has shown the osteogenic potential of plants and their active compounds. Epimedium koreanum and E. sagittatum from the Berberidaceae family contain epimedium flavonoids such as icariin, epimedin $\mathrm{A}$, and epimedin C $[38,39]$. These active flavonoids are the main constituents with anti-osteoporotic activities of these Epimedium plants [40]. Glycine max from the Fabaceae family, commonly known as soybean, is rich in proteins and flavonoids like genistein and diadzien, which are categorized as phytoestrogens [41]. These phytoestrogens displayed significant effects on bone metabolism in post-menopausal women [42-44]. Elaeis guineensis from the Arecaceae family has a high content of vitamin E, which possesses anti-inflammatory and antioxidant properties, making it suitable for anti-osteoporotic activity $[45,46]$. A study showed that compounds isolated from $T$. formosana possessed anticancer and antioxidant activities [28]. Our findings, therefore, also add T. formosana as an important bone-formation material source to the growing list of natural bioactive agents identified to have activities against osteoporosis, which may be useful for developing osteoporosis treatment strategies.

Our data provides evidence that $T$. formosana possesses an osteogenic effect. This was indicated by increases in ALP activity, mineral deposition, ER- $\alpha$ expression, and expression levels of molecular markers (Runx2, BDNF, BSP, Col-1, BMP-2, and OPN) of bone formation by the isolated active compounds, suggesting that the active compounds mediated ossification activity. Out of the six isolated compounds, 3,3'-di-O-methylellagic acid-4-O- $\alpha$-L-arabinofuranoside (1) is a novel compound, which was isolated and reported for the first time in our study. Compound $\mathbf{1}$ is an ellagic acid derivative, and is similar to a compound isolated from T. ternata [27]. Ellagic acid is a polyphenol that increases both ALP and osteocalcin (OCN) expression in male rats after tooth extraction [47]. Interestingly, several plant-derived compounds were previously shown to promote osteogenesis via regulating ER- $\alpha$ expression, which is essential for increases in both cortical and trabecular bone mass. ER- $\beta$ suppresses the signaling response of ER- $\alpha$ that is involved in bone formation [48,49]. Concordant with those findings, we also discovered that 1 robustly upregulated ER- $\alpha$ expression and downregulated ER- $\beta$ expression, suggesting that $\mathbf{1}$ may exert its osteogenic effects by modulating ER- $\alpha$ expression. Further in-depth mechanistic studies are needed to clarify exactly how $\mathbf{1}$ promotes osteogenesis [47].

Oxidative stress is caused by the overproduction of reactive oxygen species (ROS). Clinical studies have shown that ROS are associated with bone loss and low bone mineral density [50,51]. Oxidative stress damages fibronectin, a major component of extracellular matrix in bone, thus inhibiting osteoblastic mineralization [52,53]; it also activates pre-osteoclast differentiation and osteoblast apoptosis, thus enhancing bone resorption [54-57]. Given that antioxidant activity correlates with an increase in ALP [58] and that 2, 3, and $\mathbf{6}$ increased ALP activity, it is possible that upregulation of ALP activity by these compounds is due to their antioxidant activity. Interestingly, ALP was suggested to increase the concentration of inorganic phosphate, an enhancer of mineral formation, and to attenuate levels of extracellular pyrophosphate, an inhibitor of mineralization [59]. Concordant with those findings, 2, 3, and 6 elevated levels of mineral deposition. In our study, we found a similar effect, but we did not explore its antioxidant effect. Instead, we focused on studying its effect on enhancing bone formation, because the bone-related activities of $\mathbf{2}$ and $\mathbf{3}$ had never been reported before, making our study the first to describe their involvement in bone metabolism. Previous studies reported that 3 possesses antioxidant activity $[60,61]$, which could partially explain why it increased ALP activity and mineral deposition. A recent study showed that (-)-epicatechin-3-O- $\beta$-D-allopyranoside (6) is a dominant compound in the ethanolic extract of Davallia formosana, a plant with promising anti-osteoporotic activity. The anti-osteoporotic activity of $\mathbf{6}$ is mediated by inhibition of osteoclastogenesis [62]. However, in our study, as explained above, we focused on the bone formation-related activity of 6 . Compound 6 increased both ALP activity and mineralization, without displaying any significant effect on the molecular markers of bone formation except for BMP-2. This observation combined with results of previous studies suggest that 6 might be more effective in inhibiting bone resorption than promoting bone formation. 
Bone metabolism is a dynamic process that is controlled by several signaling pathways. In particular, osteoblast differentiation is mainly controlled by BMP, fibroblast growth factor (FGF), and transcription factors such as Runx2. Runx2 is essential for regulating osteogenesis and also plays key roles in osteoblast maturation. In our study, we observed that 1 increased Runx 2 expression up to 2.5 -fold, suggesting that the compound enhances osteoblast maturation. Extracellular matrix in bone is predominantly composed of Col-1 protein which initiates build-up of the bone matrix. Our results showed that $\mathbf{1}$ increased Col-1 expression up to 2.2-fold, which is essential in providing strength and elasticity to the bone and the capacity for the deposition of other matrix components [63]. Upregulation of Runx2, Col-1, and ALP indicated the induction of osteogenesis by emodin in bone marrow mesenchymal stem cells (BMSCs) [64]. Intriguingly, 1 significantly increased the expression of OPN, which regulates matrix deposition. It was also found to increase expression levels of BDNF which is reported to mediate bone morphogenetic protein (BMP)-2 expression [65]. Expression levels of BMP- 2 were also elevated by $\mathbf{1}$, thus regulating the expression of Runx 2 and increasing endochondral ossification and calcium deposition [66,67]. Our findings that $\mathbf{1}$ increased expression of all the essential genes involved in osteogenesis in $\mathrm{HOb}$ cells pinpoint $\mathbf{1}$ as an important natural product for enhancing bone formation.

In summary, our results suggested that compounds isolated from T. formosana can elevate ALP activity and mineralization. Additionally, the new compound 3,3'-di-O-methylellagic acid-4-O- $\alpha$-L-arabinofuranoside (1) upregulated factors such as BMP-2, BSP, OCN, Runx2, Col-1, and BDNF that are responsible for bone formation, suggesting that $\mathbf{1}$ possesses ossification potential. Thus, the compound can possibly be used as a nutritional supplement or as a drug to enhance bone formation in the future.

\section{Materials and Methods}

\subsection{Materials and Reagents}

Alizarin red S, 3-(4,5-dimethylthiazol-2-yl)-2,5-diphenyltetrazolium bromide (MTT), dimethyl sulfoxide- $d_{6}$ (DMSO- $\left.d_{6}\right), \beta$-glycerophosphate $\left(\beta\right.$-GP), and methanol- $d_{4}$ (Sigma-Aldrich, St. Louis, MO, USA). Cetylpyridinium chloride, $p$-nitrophenyl phosphate, sodium bicarbonate, and sodium phosphate (Mallinckrodt, St. Louis, MO, USA). Dulbecco's phosphate-buffered saline (PBS) (Gibco, Burlington, ON, Canada). Dimethyl sulfoxide (DMSO), and Triton-X 100 (J-T Baker, Phillipsburg, NJ, USA). ACS-grade ethanol and methanol (MeOH) Echo chemical, Miaoli, Taiwan). p-Nitrophenyl phosphate, sodium bicarbonate, and paraformaldehyde (Alfa Aesar, Ward Hill, MA, USA).

\subsection{General Experimental Techniques}

HPLC analysis was performed using a Hitachi L-7100 pump and an L-7420 UV-VIS detector with a reversed-phase column (Biosil ODS-W, $4.6 \times 250 \mathrm{~mm}, 10 \times 250 \mathrm{~mm}$; Biotic Chemicals, Taipei, Taiwan). UV spectra were recorded on a UV-1601 spectrophotometer (Shimadzu, Tokyo, Japan). ${ }^{1} \mathrm{H}-\mathrm{NMR}$ and ${ }^{13} \mathrm{C}-\mathrm{NMR}$ spectra were recorded on a Bruker DRX-500 MHz (Billerica, MA, USA) $\left({ }^{1} \mathrm{H}\right.$ at $500 \mathrm{MHz}$; ${ }^{13} \mathrm{C}$ at $125 \mathrm{MHz}$ ), and chemical shifts are given in $\delta$ (ppm). Two-dimensional spectra were obtained through COSY, HMQC, and HMBC experiments. ESI-MS and HRMS were carried out using an LCQ mass spectrometer and Q Exactive ${ }^{\mathrm{TM}}$ Plus Hybrid Quadrupole-Orbitrap ${ }^{\mathrm{TM}}$ Mass Spectrometer (Thermo Finnegan, Waltham, MA, USA). All solvents were distilled before use. Solvents were removed from extracts by rotary evaporation N-1000 (Eyela, Tokyo, Japan) under reduced pressure at temperatures of up to $40^{\circ} \mathrm{C}$.

\subsection{Plant Extract Preparation}

Leaves of T. formosana were obtained from and identified by Dr. Ih-Sheng Chen, College of Pharmacy, Kaohsiung Medical University (Kaohsiung, Taiwan). An herbarium voucher specimen (M387) was deposited in the Graduate Institute of Pharmacognosy, Taipei Medical University (Taipei, 
Taiwan). Dried leaves (5.3 kg) were extracted using 95\% ethanol (EtOH; $40 \mathrm{~L}$, thrice). After filtration, the mixture was concentrated using a rotary evaporator (Eyela, Tokyo, Japan) and lyophilized with a freeze-dryer (Eyela, Tokyo, Japan), and $232.0 \mathrm{~g}$ of extract was obtained.

\subsection{Isolation and Purification of Active Compounds}

The ethanolic extract of T. formosana (TF) was suspended in an aqueous solution and partitioned using $n$-hexane, ethyl acetate (EtOAc), and $n$-butanol $(n-\mathrm{BuOH})$, to obtain four layers: n-hexane at $87 \mathrm{~g}$; EtOAc at $25.1 \mathrm{~g}$; n-butanol at $41.8 \mathrm{~g}$; and an aqueous solution at $56.2 \mathrm{~g}$. The EtOAc and $n$-BuOH fractions were further subjected to chromatography using a Sephadex LH-20 (18-111 $\mu \mathrm{m}$, Amersham Pharmacia Biotech, Stockholm, Sweden) and ethanol to methanol as the gradient mobile phase. This produced nine fractions from each layer (TFEA-1-9) and (TFBU-1-9), respectively. TFEA-3 was subjected to a $\mathrm{C} 18$ column gradient of $\mathrm{H}_{2} \mathrm{O}$ to $\mathrm{MeOH}$ to obtain 10 sub-fractions (TFEA-3-1-10); following this, TFEA-3-6 was eluted using a C18 gradient to obtain two sub-fractions (TFEA-3-6-1 and TFEA-3-6-2). CP-1 (109.7 mg) was collected after purification of TFEA-3-6-1 using HPLC RP-ODS 35\% $\mathrm{MeOH}$ (see Chart S1, Supplementary Materials).

\subsection{Cell Culture}

Primary human osteoblast $(\mathrm{HOb})$ cells from a normal femur of a 63-year-old Caucasian female were purchased from Cell Applications (San Diego, CA, USA). Cells were cultured in osteoblast growth medium (OGM, Cell Applications, San Diego, CA, USA) for proliferation. For differentiation, osteoblast differentiation medium (ODM, Cell Applications, San Diego, CA, USA) was used. ODM containing ascorbic acid, dexamethasone, and $\beta$-glycerophosphate was purchased from Sigma-Aldrich (St. Louis, MO, USA), for mineralization at $37^{\circ} \mathrm{C}$ in a $5 \% \mathrm{CO}_{2}$ humidified atmosphere [68] (ODM for mineralization is represented as ODM miner in this study).

\subsection{MTT Assay for Cell Viability Assay}

The viability of $\mathrm{HOb}$ cells was evaluated using an MTT assay. Cells at $4 \times 10^{3}$ per well in OGM were seeded in a 96-well plate. After one day, fresh OGM with 1-6 was added to cells. After five days, medium was replaced by fresh OGM containing $0.5 \mathrm{mg} / \mathrm{mL}$ MTT reagent and incubated for $4 \mathrm{~h}$ at $37^{\circ} \mathrm{C}$ in a $5 \% \mathrm{CO}_{2}$ atmosphere. Medium was removed, and DMSO was used to dissolve the formazan crystals. The optical density (OD) was measured using a microplate reader (Bio-Tek Instruments, Winooski, VT, USA) at $600 \mathrm{~nm}[68,69]$.

\subsection{ALP Activity Assay}

Cells $\left(4 \times 10^{3}\right.$ per well in OGM) were seeded in a 96-well plate. After one day, fresh OGM containing samples or positive controls was added. Three days after this, medium was removed, PBS was used for washing, and lysis buffer (0.1\% Triton X-100 in PBS) was used to lyse cells. The lysate was separated into different wells for ALP and bicinchonic acid (BCA). The $p$-nitrophenyl phosphate substrate (in $6 \mathrm{mM} \mathrm{NaHCO} 3-\mathrm{Na}_{2} \mathrm{CO}_{3}$ buffer, $\mathrm{pH}$ 10) was added to wells with lysate for ALP and the BCA protein assay reagent to respective wells. The reaction was allowed to proceed for $1 \mathrm{~h}$ at $37^{\circ} \mathrm{C}$. ODs were measured using a microplate reader at 405 and $560 \mathrm{~nm}$ for ALP and BCA, respectively. ALP activity was determined by ALP value/BCA value, and normalized to the control as $100 \%[68,70]$.

\subsection{Mineralization Assay}

$\mathrm{HOb}$ cells were seeded at the density of $4 \times 10^{4}$ cells per well in a 48 -well plate using OGM. After three days, fresh ODM miner containing inducers, active compounds, or the positive control was added. Every two days, freshly prepared ODM miner containing test samples was added. After 11 days, medium was removed, PBS was used to wash $\mathrm{HOb}$ cells, and then $4 \%$ paraformaldehyde was added for $20 \mathrm{~min}$ at room temperature to fix the cells. Cells were washed with PBS twice, and $40 \mathrm{mM}$ 
alizarin red S dye was added for $20 \mathrm{~min}$ at room temperature. After removing the dye, water was used to wash out any extra dye; this was followed by photographing the samples. For the quantitative analysis, $10 \%$ cetylpyridinium chloride (in $10 \mathrm{mM}$ sodium phosphate, $\mathrm{pH}$ 7.0) was used to dissolve crystals, and the solution was transferred to a 96-well plate. A microplate reader was used to measure the $\mathrm{OD}$ at $550 \mathrm{~nm}[68,71]$.

\subsection{RNA Isolation and Reverse Transcription}

Gene expression levels in $\mathrm{HOb}$ cells were measured using a real-time polymerase chain reaction (PCR). $\mathrm{HOb}$ cells $\left(7 \times 10^{5}\right)$ in OGM were seeded in 6-cm dishes. After one day, fresh ODM containing active compounds or the positive control was added. After $24 \mathrm{~h}$, cells were collected and centrifuged for $5 \mathrm{~min}$ at $3000 \mathrm{rpm}$ and $4{ }^{\circ} \mathrm{C}$ [68]. For RNA isolation, a High Pure RNA Isolation Kit (Roche, Mannheim, Germany) was used according to the manufacturer's instructions. The concentration and quality of RNA samples were detected using a Nanodrop 2000c (Thermo Scientific, Waltham, MA, USA). The eluted RNA was stored at $-80^{\circ} \mathrm{C}$ for later analysis.

A high-capacity complementary (c)DNA reverse-transcription kit (Thermo Scientific, Waltham, MA, USA) was used to make cDNA according to the manufacturer's instructions. The reaction took place in the following thermal cycle: $25^{\circ} \mathrm{C}$ for $10 \mathrm{~min}, 37^{\circ} \mathrm{C}$ for $120 \mathrm{~min}, 80^{\circ} \mathrm{C}$ for $5 \mathrm{~min}$, and $4{ }^{\circ} \mathrm{C}$ for $60 \mathrm{~min}$. cDNA was stored at $-20^{\circ} \mathrm{C}$ until further analysis [72].

\subsection{Real-Time Quantitative PCR Analysis}

The real-time PCR mix contained $5 \mu \mathrm{L}$ LightCycler ${ }^{\circledR} 480$ probe master (Roche, Mannheim, Germany), $0.4 \mu \mathrm{L}$ forward and reverse primers, $0.2 \mu \mathrm{L}$ Universal Probe Library (UPL) probes (Roche), and 3.4 $\mu \mathrm{L}$ nuclease-free $\mathrm{H}_{2} \mathrm{O}$ for each well. cDNA samples at $1 \mu \mathrm{L} /$ well were added to a specific 96 -well plate; this was followed by adding $9 \mu \mathrm{L}$ of the reaction mix, to make a final volume of $10 \mu \mathrm{L}$ in each well. Sequences of the primers and respective probe numbers are shown in Table 2. Gene expression results were analyzed using Livak's formula $\left(2^{(-\Delta \Delta \mathrm{Ct})}\right.$ method), normalized against GAPDH expression (as a housekeeping gene) and are expressed as the relative expression compared to that of the control. Cycling parameters for the LightCycler ${ }^{\circledR} 480$ system (Roche) were set as follows: pre-incubation at 95 ${ }^{\circ} \mathrm{C}$ for $10 \mathrm{~min}$, amplification followed by 50 cycles of $95^{\circ} \mathrm{C}$ (for $10 \mathrm{~s}$ ), $60^{\circ} \mathrm{C}$ (for $30 \mathrm{~s}$ ), and $72{ }^{\circ} \mathrm{C}$ (for $1 \mathrm{~s}$ ), followed by a cooling step of $30 \mathrm{~s}$ at $40{ }^{\circ} \mathrm{C}[68]$.

Table 2. Primer and probe combination used for the real-time PCR.

\begin{tabular}{|c|c|c|c|}
\hline & & Sequence $\left(5^{\prime} \rightarrow 3^{\prime}\right)$ & Probe Number \\
\hline \multirow{2}{*}{ Runx-2 } & Forward & CAGTGACACCATGTCAGCAA & \multirow{2}{*}{41} \\
\hline & Reverse & GCTCACGTCGCTCATTTTG & \\
\hline \multirow{2}{*}{ OPN } & Forward & GGGCTTGGTTGTCAGCAG & \multirow{2}{*}{63} \\
\hline & Reverse & TGCAATTCTCATGGTAGTGAGTTT & \\
\hline \multirow{2}{*}{ BMP-2 } & Forward & CGGACTGCGGTCTCCTAA & \multirow{2}{*}{49} \\
\hline & Reverse & GGAAGCAGCAACGCTAGAAG & \\
\hline \multirow{2}{*}{ BSP } & Forward & GATTTCCAGTTCAGGGCAGT & \multirow{2}{*}{63} \\
\hline & Reverse & TCTCСТTCATTTGAAGTCTCСТСТ & \\
\hline \multirow{2}{*}{ Col-1 } & Forward & AGGTCCCCCTGGAAAGAA & \multirow{2}{*}{60} \\
\hline & Reverse & AATCCTCGAGCACCCTGA & \\
\hline \multirow{2}{*}{ BDNF } & Forward & AGAATCGGAACCACGATTTG & \multirow{2}{*}{70} \\
\hline & Reverse & TCTCACCTGGTGGAACTCG & \\
\hline \multirow{2}{*}{ GAPDH } & Forward & AGCCACATCGCTCAGACAC & \multirow{2}{*}{60} \\
\hline & Reverse & GCCCAATACGACCAAATCC & \\
\hline
\end{tabular}




\subsection{Estrogen Receptor Expression Assay}

$\mathrm{HOb}$ cells at a density of $4 \times 10^{3}$ cells per well in OGM were seeded in a 96-well plate. After $24 \mathrm{~h}$, fresh OGM containing active compounds or the positive control was added. After five days of incubation, expressions levels of ER- $\alpha$ and $-\beta$ were analyzed using ESR1 and ESR2 (human) cell-based enzyme-linked immunosorbent assay (ELISA) kits (Abnova, Walnut, CA, USA) according to the manufacturer's instructions [73].

\subsection{Statistical Analysis}

Statistical analyses were performed with SigmaPlot (11.0, SYSTAT, Chicago, IL, USA). A one-way analysis of variance (ANOVA) with the Student-Newman-Keuls analysis was conducted to determine statistical significance. $p<0.05$ was considered statistically significant.

Supplementary Materials: Supplementary materials can be found at http://www.mdpi.com/1422-0067/20/13/ 3119/s1.

Author Contributions: Study design, M.-H.L. and Z.I.; methodology, Z.I. and Y.-F.W.; validation and analysis, M.-H.L., Z.I., H.-K.L., and Y.-T.L.; investigation, Z.I. and Y.-F.W.; resources, M.-H.L.; manuscript draft preparation, Z.I., Y.-T.L. and M.-H.L.; manuscript review and editing, Z.I. and M.-H.L.; supervision and funding acquisition M.-H.L.

Funding: This study was supported by the Ministry of Science and Technology, Taiwan under grant number NSC101-2320-B-038-014-MY3.

Acknowledgments: We would like to extend our gratitude to Ih-Sheng Chen, College of Pharmacy, Kaohsiung Medical University for helping us with collecting and identifying the plant material.

Conflicts of Interest: The authors declare no conflict of interest.

\section{References}

1. Harvey, N.; Dennison, E.; Cooper, C. Osteoporosis: Impact on health and economics. Nat. Rev. Rheumatol. 2010, 6, 99-105. [CrossRef] [PubMed]

2. Florencio-Silva, R.; Sasso, G.R.D.S.; Sasso-Cerri, E.; Sim, M.J.; Cerri, P.S. Biology of bone tissue: Structure, function, and factors that influence bone cells. Biomed. Res. Int. 2015, 2015, 1-17. [CrossRef] [PubMed]

3. Robling, A.G.; Castillo, A.B.; Turner, C.H. Biochemical and molecular regulation of bone remodelling. Annu. Rev. Biomed. Eng. 2006, 8, 455-498. [CrossRef] [PubMed]

4. Hadjidakis, D.J.; Androulakis, I.I. Bone remodeling. Ann. N. Y. Acad. Sci. 2006, 1092, 385-396. [CrossRef] [PubMed]

5. Reid, I.R. Efficacy, effectiveness and side effects of medications used to prevent fractures. J. Intern. Med. 2015, 277, 690-706. [CrossRef]

6. Murad, M.H.; Drake, M.T.; Mullan, R.J.; Mauck, K.F.; Stuart, L.M.; Lane, M.A.; Abu Elnour, N.O.; Erwin, P.J.; Hazem, A.; Puhan, M.A.; et al. Comparative effectiveness of drug treatments to prevent fragility fractures: A systematic review and network meta-analysis. J. Clin. Endocrinol. Metab. 2012, 97, 1871-1880. [CrossRef]

7. Lim, S.Y.; Bolster, M.B. Current approaches to osteoporosis treatment. Curr. Opin. Rheumatol. 2015, 27, 216-224. [CrossRef]

8. Tabatabaei-Malazy, O.; Salari, P.; Khashayar, P.; Larijani, B. New horizons in treatment of osteoporosis. Daru. 2017, 25, 1-16. [CrossRef]

9. Watts, N.B.; Bilezikian, J.P.; Camacho, P.M.; Greenspan, S.L.; Harris, S.T.; Hodgson, S.F.; Kleerekoper, M.; Luckey, M.M.; McClung, M.R.; Pollack, R.P.; et al. American association of clinical endocrinologists medical guidelines for clinical practice for the diagnosis and treatment of postmenopausal osteoporosis. Endocr. pract. 2010, 16, 1-37. [CrossRef]

10. Rossouw, J.E.; Anderson, G.L.; Prentice, R.L.; LaCroix, A.Z.; Kooperberg, C.; Stefanick, M.L.; Jackson, R.D.; Beresford, S.A.; Howard, B.V.; Johnson, K.C.; et al. Risks and benefits of estrogen plus progestin in healthy postmenopausal women: Principal results from the women's health initiative randomized controlled trial. Jama 2002, 288, 321-333.

11. Cosman, F.; de Beur, S.J.; LeBoff, M.S.; Lewiecki, E.M.; Tanner, B.; Randall, S.; Lindsay, R. Clinician's guide to prevention and treatment of osteoporosis. Osteoporos Int. 2014, 25, 2359-2381. [CrossRef] [PubMed] 
12. Uusi-Rasi, K.; Sievänen, H.; Pasanen, M.; Beck, T.J.; Kannus, P. Influence of calcium intake and physical activity on proximal femur bone mass and structure among pre- and postmenopausal women. A 10-Year prospective study. Calcif. Tissue Int. 2008, 82, 171-181. [CrossRef] [PubMed]

13. Lewis, J.R.; Zhu, K.; Prince, R.L. Adverse events from calcium supplementation: Relationship to errors in myocardial infarction self-reporting in randomized controlled trials of calcium supplementation. J. Bone Miner. Res. 2012, 27, 719-722. [CrossRef] [PubMed]

14. Golub, E.E.; Boesze-Battaglia, K. The role of alkaline phosphatase in mineralization. Curr. Opin. Orthop. 2007, 18, 444-448. [CrossRef]

15. Yoshida, C.A.; Yamamoto, H.; Fujita, T.; Furuichi, T.; Ito, K.; Inoue, K.; Yamana, K.; Zanma, A.; Takada, K.; Ito, Y.; et al. Runx2 and Runx3 are essential for chondrocyte maturation, and Runx2 regulates limb growth through induction of Indian hedgehog. Genes Dev. 2004, 18, 952-963. [CrossRef] [PubMed]

16. Komori, T. Roles of Runx2 in skeletal development. Adv. Exp. Med. Biol. 2017, 962, 83-93.

17. Viguet-Carrin, S.; Garnero, P.; Delmas, P.D. The role of collagen in bone strength. Osteoporos Int. 2006, 17, 319-336. [CrossRef]

18. Nudelman, F.; Pieterse, K.; George, A.; Bomans, P.H.H.; Friedrich, H.; Brylka, L.J.; Hilbers, P.A.J.; de With, G.; Sommerdijk, N.A.J.M. The role of collagen in bone apatite formation in the presence of hydroxyapatite nucleation inhibitors. Nat. Mater. 2010, 9, 1004-1009. [CrossRef]

19. Niyibizi, C.; Eyre, D.R. Structural characteristics of cross-linking sites in type V Collagen of bone. Eur. J. Biochem. 1994, 224, 943-950. [CrossRef]

20. Standal, T.; Borset, M.; Sundan, A. Role of osteopontin in adhesion, migration, cell survival and bone remodeling. J. Clin. Exp. Oncol. 2004, 26, 179-184.

21. Denhardt, D.T.; Noda, M. Osteopontin expression and function: Role in bone remodeling. J. Cell. Biochem. 1998, 72, 92-102. [CrossRef]

22. Vaananen, H.K.; Harkonen, P.L. Estrogen and bone metabolism. Maturitas 1996, 23, S65-S69. [CrossRef]

23. Klein-Nulend, J.; van Oers, R.F.M.; Bakker, A.D.; Bacabac, R.G. Bone cell mechanosensitivity, estrogen deficiency, and osteoporosis. J. Biomech. 2015, 48, 855-865. [CrossRef] [PubMed]

24. Riggs, B.L. The mechanisms of estrogen regulation of bone resorption. J. Clin. Invest. 2000, 106, $1203-1204$. [CrossRef] [PubMed]

25. Horgen, F.; Edrada, R.; De Los Reyes, G.; Agcaoili, F.; Madulid, D.; Wongpanich, V.; Angerhofer, C.; Pezzuto, J.; Soejarto, D.; Farnsworth, N. Biological screening of rain forest plot trees from Palawan Island (Philippines). Phytomedicine 2001, 8, 71-81. [CrossRef] [PubMed]

26. Jantová, S.; Nagy, M.; Ruzeková, L.; Grancai, D. Antibacterial activity of plant extracts from the families Fabaceae, Oleaceae, Philadelphaceae, Rosaceae and Staphyleaceae. Phytother Res. 2000, 14, 601-603. [CrossRef]

27. Matthew, S.; Kao, K.C.; Chang, Y.S.; Abreu, P. Ellagic acid glycosides from Turpinia ternata. Nat. Prod. Res. 2007, 21, 83-88. [CrossRef] [PubMed]

28. Huang, H.C.; Chiou, C.T.; Hsiao, P.C.; Liaw, C.C.; Zhang, L.J.; Chang, C.L.; Chen, I.S.; Chen, W.C.; Lee, K.H.; Kuo, Y.H. Cytotoxic phenylpropanoids and a new triterpene, turformosinic acid, from Turpinia formosana Nakai. Molecules 2012, 17, 1837-1851. [CrossRef]

29. Tang, C.; Zhang, H.; Wang, Y.; Xie, N.; Lv, W.; Yang, X.; Liu, D.; Li, Z.; Cheng, F. Method for manufacturing water extract of turpinia formosana for treating influenza. CN Patent CN101884651A, 17 Novomber 2010.

30. Tang, C.; Wang, Y.; Zhang, H.; Xie, N.; Lv, W.; Yang, X.; Liu, D.; Li, Z.; Cheng, F. Method for manufacturing ethanol extract of turpinia formosana for preventing and treating influenza. CN Patent CN101879197A, 17 Novomber 2010.

31. Ou, J.; Hsieh, W.; Lin, I.; Chang, Y.; Chen, I. The catalogue of medicinal plant resources in Taiwan; Department of Health, Executive Yuan: Taipei, Taiwan, 2003.

32. Zhou, Y.; Chen, H.B.; Wang, B.; Liang, H.; Zhao, Y.Y.; Zhang, Q.Y. Sesquiterpenoid and phenolic glucoside gallates from Lagerstroemia balansae. Planta Med. 2011, 77, 1944-1956. [CrossRef]

33. Kazaki, K. Casuarin, stachyurin and strictinin, new ellagitannins from casuarina stricta and stachyurus praecox. Chem. Pharm. Bull. 1982, 30, 766-769.

34. Cui, C.B.; Tezuka, Y.; Kikuchi, T.; Nakano, H.; Tamaoki, T.; Park, J.H. Constituents of a Fern, Davallia mariesii MOORE. IV. Isolation and structures of a novel norcarotane sesquiterpene glycoside, a chromone glucuronide, and two epicatechin glycosides. Chem. Pharm. Bull. 1992, 40, 2035-2040. [CrossRef] 
35. Li, X.C.; Elsohly, H.N.; Hufford, C.D.; Clark, A.M. NMR assignments of ellagic acid derivatives. Magn. Reson. Chem. 1999, 37, 856-859. [CrossRef]

36. Benesi, A.J.; Falzone, C.J.; Banerjee, S.; Farber, G.K. NMR assignments for the aldopentoses. Carbohydr. Res. 1994, 258, 27-33. [CrossRef]

37. Murshed, M. Mechanism of bone mineralization. Cold Spring Harb Perspect Med. 2018, 8, 1-12. [CrossRef] [PubMed]

38. Hsieh, T.P.; Sheu, S.Y.; Sun, J.S.; Chen, M.H.; Liu, M.H. Icariin isolated from Epimedium pubescens regulates osteoblasts anabolism through BMP-2, SMAD4, and Cbfa1 expression. Phytomedicine 2010, 17, 414-423. [CrossRef] [PubMed]

39. Ma, H.; He, X.; Yang, Y.; Li, M.; Hao, D.; Jia, Z. The genus Epimedium: An ethnopharmacological and phytochemical review. J. Ethnopharmacol. 2011, 134, 519-541. [CrossRef] [PubMed]

40. Jolly, J.J.; Chin, K.-Y.; Alias, E.; Chua, K.H.; Soelaiman, I.N. Protective effects of selected botanical agents on bone. Int. J. Environ. Res. Public Health 2018, 15, 963. [CrossRef] [PubMed]

41. Liu, X.L.; Li, J.H.; Yang, Y.F.; Zhu, J.Y. Floral development of gymnospermium microrrhynchum (berberidaceae) and its systematic significance in the nandinoideae. Flora 2017, 228, 10-16. [CrossRef]

42. Lambert, M.N.T.; Thybo, C.B.; Lykkeboe, S.; Rasmussen, L.M.; Frette, X.; Christensen, L.P.; Jeppesen, P.B. Combined bioavailable isoflavones and probiotics improve bone status and estrogen metabolism in postmenopausal osteopenic women: A randomized controlled trial. Am. J. Clin. Nutr. 2017, 106, 909-920. [CrossRef]

43. Ricci, E.; Cipriani, S.; Chiaffarino, F.; Malvezzi, M.; Parazzini, F. Soy isoflavones and bone mineral density in perimenopausal and postmenopausal Western women: A systematic review and meta-analysis of randomized controlled trials. J. Womens Health 2010, 19, 1609-1617. [CrossRef]

44. Taku, K.; Melby, M.K.; Kurzer, M.S.; Mizuno, S.; Watanabe, S.; Ishimi, Y. Effects of soy isoflavone supplements on bone turnover markers in menopausal women: Systematic review and meta-analysis of randomized controlled trials. Bone 2010, 47, 413-423. [CrossRef] [PubMed]

45. McLean, R.R. Proinflammatory cytokines and osteoporosis. Curr. Osteoporos. Rep. 2009, 7, $134-139$. [CrossRef] [PubMed]

46. Shen, C.L.; Klein, A.; Chin, K.Y.; Mo, H.; Tsai, P.; Yang, R.S.; Chyu, M.C.; Ima-Nirwana, S. Tocotrienols for bone health: A translational approach. Ann. N. Y. Acad. Sci. 2017, 1401, 150-165. [CrossRef] [PubMed]

47. Al-Obaidi, M.M.; Al-Bayaty, F.H.; Al Batran, R.; Ibrahim, O.E.; Daher, A.M. Ellagic acid increases osteocalcin and alkaline phosphatase after tooth extraction in nicotinic-treated rats. Curr. Pharm. Des. 2016, 22, 2403-2410. [CrossRef] [PubMed]

48. Guo, A.J.; Choi, R.C.; Zheng, K.Y.; Chen, V.P.; Dong, T.T.; Wang, Z.T.; Vollmer, G.; Lau, D.T.; Tsim, K.W. Kaempferol as a flavonoid induces osteoblastic differentiation via estrogen receptor signaling. Chin. Med. 2012, 7, 1-7. [CrossRef] [PubMed]

49. Lee, C.H.; Huang, Y.L.; Liao, J.F.; Chiou, W.F. Ugonin K-stimulated osteogenesis involves estrogen receptor-dependent activation of non-classical Src signaling pathway and classical pathway. Eur. J. Pharmacol. 2012, 676, 26-33. [CrossRef]

50. Baek, K.H.; Oh, K.W.; Lee, W.Y.; Lee, S.S.; Kim, M.K.; Kwon, H.S.; Rhee, E.J.; Han, J.H.; Song, K.H.; Cha, B.Y.; et al. Association of oxidative stress with postmenopausal osteoporosis and the effects of hydrogen peroxide on osteoclast formation in human bone marrow cell cultures. Calcif. Tissue Int. 2010, 87, 226-235. [CrossRef]

51. Ostman, B.; Michaelsson, K.; Helmersson, J.; Byberg, L.; Gedeborg, R.; Melhus, H.; Basu, S. Oxidative stress and bone mineral density in elderly men: Antioxidant activity of alpha-tocopherol. Free Radic. Biol. Med. 2009, 47, 668-673. [CrossRef]

52. Gao, J.; Feng, Z.; Wang, X.; Zeng, M.; Liu, J.; Han, S.; Xu, J.; Chen, L.; Cao, K.; Long, J.; et al. SIRT3/SOD2 maintains osteoblast differentiation and bone formation by regulating mitochondrial stress. Cell Death Differ. 2018, 25, 229-240. [CrossRef]

53. Abdollahi, M.; Larijani, B.; Rahimi, R.; Salari, P. Role of oxidative stress in osteoporosis. Therapy 2005, 2, 787-796. [CrossRef]

54. Lean, J.M.; Jagger, C.J.; Kirstein, B.; Fuller, K.; Chambers, T.J. Hydrogen peroxide is essential for estrogen-deficiency bone loss and osteoclast formation. Endocrinology 2005, 146, 728-735. [CrossRef] [PubMed] 
55. Huh, Y.J.; Kim, J.M.; Kim, H.; Song, H.; So, H.; Lee, S.Y.; Kwon, S.B.; Kim, H.J.; Kim, H.H.; Lee, S.H.; et al. Regulation of osteoclast differentiation by the redox-dependent modulation of nuclear import of transcription factors. Cell Death Differ. 2006, 13, 1138-1146. [CrossRef] [PubMed]

56. Henriksen, K.; Neutzsky-Wulff, A.V.; Bonewald, L.F.; Karsdal, M.A. Local communication on and within bone controls bone remodeling. Bone 2009, 44, 1026-1033. [CrossRef] [PubMed]

57. Wilson, C. Oxidative stress and osteoporosis. Nat. Rev. Endocrinol. 2013, 10, 3. [CrossRef] [PubMed]

58. Domazetovic, V.; Marcucci, G.; Iantomasi, T.; Brandi, M.L.; Vincenzini, M.T. Oxidative stress in bone remodeling: Role of antioxidants. Clin. Cases Miner. Bone Metab. 2017, 14, 209-216. [CrossRef] [PubMed]

59. Orimo, H. The mechanism of mineralization and the role of alkaline phosphatase in health and disease. J. Nippon. Med. Sch. 2010, 77, 4-12. [CrossRef] [PubMed]

60. Chen, G.H.; Lin, Y.L.; Hsu, W.L.; Hsieh, S.K.; Tzen, J.T.C. Significant elevation of antiviral activity of strictinin from Pu'er tea after thermal degradation to ellagic acid and gallic acid. J. Food Drug Anal. 2015, 23, 116-123. [CrossRef] [PubMed]

61. Hsieh, S.-K.; Xu, J.-R.; Lin, N.-H.; Li, Y.-C.; Chen, G.-H.; Kuo, P.-C.; Chen, W.-Y.; Tzen, J.T.C. Antibacterial and laxative activities of strictinin isolated from Pu'er tea (Camellia sinensis). J. Food Drug Anal. 2016, 24, 722-729. [CrossRef] [PubMed]

62. Ko, Y.-J.; Wu, J.-B.; Ho, H.-Y.; Lin, W.-C. Antiosteoporotic activity of Davallia formosana. J. Ethnopharmacol. 2012, 139, 558-565. [CrossRef]

63. Phan, T.C.; Xu, J.; Zheng, M.H. Interaction between osteoblast and osteoclast: Impact in bone disease. Histol Histopathol. 2004, 19, 1325-1344.

64. Yang, F.; Yuan, P.-W.; Hao, Y.-Q.; Lu, Z.-M. Emodin enhances osteogenesis and inhibits adipogenesis. BMC Complement. Altern. Med. 2014, 14, 74-83. [CrossRef] [PubMed]

65. Gratacòs, E.; Checa, N.; Pérez-Navarro, E.; Alberch, J. Brain-derived neurotrophic factor (BDNF) mediates bone morphogenetic protein-2 (BMP-2) effects on cultured striatal neurones. J. Neurochem. 2001, 79, 747-755. [CrossRef] [PubMed]

66. Zamurovic, N.; Cappellen, D.; Rohner, D.; Susa, M. Coordinated activation of notch, Wnt, and transforming growth factor-beta signaling pathways in bone morphogenic protein 2-induced osteogenesis. Notch target gene Hey1 inhibits mineralization and Runx2 transcriptional activity. J. Biol. Chem. 2004, 279, 37704-37715. [CrossRef] [PubMed]

67. Wang, R.N.; Green, J.; Wang, Z.; Deng, Y.; Qiao, M.; Peabody, M.; Zhang, Q.; Ye, J.; Yan, Z.; Denduluri, S.; et al. Bone Morphogenetic Protein (BMP) signaling in development and human diseases. Genes Dis. 2014, 1, 87-105. [CrossRef] [PubMed]

68. Mao, Y.W.; Lin, R.D.; Hung, H.C.; Lee, M.H. Stimulation of osteogenic activity in human osteoblast cells by edible Uraria crinita. J. Agric. Food Chem. 2014, 62, 5581-5588. [CrossRef] [PubMed]

69. Scudiero, D.A.; Shoemaker, R.H.; Paull, K.D.; Monks, A.; Tierney, S.; Nofziger, T.H.; Currens, M.J.; Seniff, D.; Boyd, M.R. Evaluation of a soluble tetrazolium/formazan assay for cell growth and drug sensitivity in culture using human and other tumor cell lines. Cancer Res. 1988, 48, 4827-4833. [PubMed]

70. Hsu, Y.L.; Chang, J.K.; Tsai, C.H.; Chien, T.T.; Kuo, P.L. Myricetin induces human osteoblast differentiation through bone morphogenetic protein-2/p38 mitogen-activated protein kinase pathway. Biochem. Pharmacol. 2007, 73, 504-514. [CrossRef]

71. Wang, Y.H.; Liu, Y.; Maye, P.; Rowe, D.W. Examination of mineralized nodule formation in living osteoblastic cultures using fluorescent dyes. Biotechnol. progr. 2006, 22, 1697-1701. [CrossRef]

72. Bhadang, K.A.; Holding, C.A.; Thissen, H.; McLean, K.M.; Forsythe, J.S.; Haynes, D.R. Biological responses of human osteoblasts and osteoclasts to flame-sprayed coatings of hydroxyapatite and fluorapatite blends. Acta biomater. 2010, 6, 1575-1583. [CrossRef]

73. Chou, C.W.; Chiang, T.I.; Chang, I.C.; Huang, C.H.; Cheng, Y.W. Expression levels of estrogen receptor alpha mRNA in peripheral blood cells are an independent biomarker for postmenopausal osteoporosis. BBA Clin. 2016, 5, 124-129. [CrossRef]

(C) 2019 by the authors. Licensee MDPI, Basel, Switzerland. This article is an open access article distributed under the terms and conditions of the Creative Commons Attribution (CC BY) license (http://creativecommons.org/licenses/by/4.0/). 